DOI: https://doi.org/10.24127/ajpm.v10i4.4416

\title{
KEMAMPUAN PEMECAHAN MASALAH DAN KEMANDIRIAN BELAJAR MENGGUNAKAN PENDEKATAN STEM BERBASIS LESSON STUDY FOR LEARNING COMMUNITY
}

\author{
Andini Dwi Rachamawati ${ }^{*}$, Yaya S. Kusumah ${ }^{2}$, Dadang Juandi ${ }^{3}$ \\ ${ }^{1 * 2,3}$ Universitas Pendidikan Indonesia, Bandung, Indonesia \\ *Corresponding author. \\ E-mail: $\quad$ andinidwirachmawati@upi.edu $^{\left.{ }^{*}\right)}$ \\ yayaskusumah@upi.edu ${ }^{2)}$ \\ dadangjuandi@upi.edu ${ }^{3)}$
}

Received 10 November 2021; Received in revised form 16 November 2021; Accepted 23 December 2021

\begin{abstract}
Abstrak
Penelitian ini bertujuan untuk mendeskripsikan kemampuan pemecahan masalah dan kemandriain belajar dengan pendekatan STEM berbasis LSLC (Lesson Study for Learning Community). Subjek penelitian adalah enam peserta didik kelas VII SMPN 1 Ngunut. Pemilihan subjek peserta didik berdasarkan angket kemandirain belajar. Penelitian ini tergolong penelitian kualitatif . Teknik pengumpulan data pada penelitian terdiri dari beberapa tahapan yaitu lembar observasi, angket kemandirian belajar, dan tes kemampuan pemecahan masalah matematika. Analisis data yang diigunakan pada penelitian ini yaitu dengan pengumpulan data, penyajian data, dan verifikasi data. Hasil penelitian ini menunjukkan bahwa aktivitas belajar peserta didik mengalami peningkatan. setiap pertemuan. Perkembangan tersebut dapat ditunjukkan dengan kemampuan pemecahan masalah dengan kemandirian belajar tinggi, mampu menyelesaikan masalah menggunakan empat tahap. Hanya tiga indikator yang dapat dicapai oleh peserta didik yang memiliki kemapuan pemecahan masalah matematika dengan kemandirian belajar sedang Sedangkan peserta didik dengan kemampuan pemecahan masalah matematika dengan kemandirian belajar rendah hanya memenuhi satu indikator saja.
\end{abstract}

Kata kunci: Kemampuan pemecahan masalah; kemandiran belajaran; LSLC pendekatan STEM.

\begin{abstract}
This study aims to describe problem solving skills and independent learning with a STEM approach based on LSLC (Lesson Study for Learning Community). The research subjects were six seventh grade students of SMPN 1 Ngunut. The selection of students' subjects was based on a self-learning questionnaire. This research is classified as qualitative research. The data collection technique in the study consisted of several stages, namely observation sheets, learning independence questionnaires, and mathematical problem solving ability tests. Data analysis used in this study is data collection, data presentation, and data verification. The results of this study indicate that the learning activities of students have increased. every meeting. This development can be shown by problem solving skills with high learning independence, able to solve problems using four stages. Only three indicators can be achieved by students who have mathematical problem solving abilities with moderate learning independence. Meanwhile, students with mathematical problem solving abilities with low learning independence only meet one indicator.
\end{abstract}

Keywords: Problem solving ability; LSLC; learning independence; STEM approach.

This is an open access article under the Creative Commons Attribution 4.0 International License

\section{PENDAHULUAN}

NCTM (2000) menekakan bahwa ada kemampuan yang dimiliki peserta didik yaitu pemecahan masalah (problem solving), penalaran dan bukti (reason and proof), komunikasi (communication), dan representasi (representation). pemecahan masalah merupakan kemampuan yang mengarahkan 
pemikiran sesorang dalam mencari solusi permasalahan secara spesifik (Murdiyani et al., 2013). Kemampuan pemecahan masalah juga dapat melibatkan peserta didik dalam memahami dan menguasai strategi yang lebih kompleks (Abdullah et al., 2014; Simamora et al., 2018).

Berkembangnya kemampuan pemecahan masalah setiap peserta didik dapat dilakukan dengan langkah yang lebih sistematis dengan mengikuti langkah polya (Sam \& Qohar, 2016). Langkah polya yang harus diterapkan pada peserta didik diantaranya (1) memahami masalah (understanding the problem), (2) menyusun rencana (devising a plan), (3) melaksanakan rencana (carrying out the plan), dan (4) melihat kembali (looking back) (Razak et al., 2018). Melaui langkah polya peserta didik nantinya mampu menyelesaikan masalah dengan baik, mengolah informasi dengan referensi yang relevan, dan menganalisis kembali solusi masalah yang diberikan (Wulandari et al., 2019).

Faktor yang mendukung adanya peningkatan kemampuan pemecahan masalah adalah kemandirian belajar (Ekananda et al., 2020). Lebih dari itu, kemandirian belajar dapat mempermudah peserta didik dalam menelaah kebutuhan dan menetapkan tujuan belajar (Ekawati et al., 2018). Lantaran, kemandirian belajar setiap peserta didik akan menggambarkan perilakunya saat kegiatan belajar mengajar (Hurst et al., 2013).

Kemampuan pemecahan masalah dan kemandirian belajar dapat berkembang dengan baik apabila pendidik dapat mencipatakan suasana belajar yang mampu menarik perhatian peserta didik (Darling-Hammond et al., 2019). Pengintergrasian pendekatan STEM kedalam kurikulum sekolah memiliki tujuan untuk mengeksploitasi kemampuan pemecahan masalah (Siregar et al., 2019).

Terdapat beberapa disiplin ilmu yang terkandung dalam pendekatan STEM yaitu: (1) science, memunculkan ketertarikan dan pemahaman tentang ilmu pengetahuan; (2) technology, melibatkan aplikasi keilmuan, kemampuan berpikir komputasi untuk mengembangkan keahlian peserta didik; (3) engineering, mendesain dan merancang produk guna mempermudah dalam menyelesaikan masalah dalam kehidupan sehari - hari; (4) mathematics, menganalisis, menyederhanakan dan menarik kesimpulan sesuai informasi yang diperoleh melalui pemodelan baik secara abstrak maupun konkret (Frey, 2018). Empat disiplin ilmu yang terkandung dalam pendekatan STEM mampu membantu peserta didik dalam memahami konsep sains dan keterkaitan dengan kehidupan sehari - hari

Agar interaksi dalam kegiatan belajar mengajar dapat terjadi dengan lancar perlu adanya penerapan Lesson Study for Learning Community (LSLC) (Widoretno \& Dwiastuti, 2019). Bjuland \& Mosvold (2015) menyatakan bahwa LSLC merupakan kolaborasi antara pendidik dan peserta didik dalam meninjau kembali isi dan tugas belajar setelah melakukan diskusi. Proses kolaborasi yang telah terjadi nantinya akan memupuk peserta didik saling bekerjasama.

LSLC dilakukan dengan tiga tahapan yaitu perencanaan (plan), melaksanakan (do), merefleksikan (see). Unsur - unsur utama LSLC adalah (1) collaborative learning, dimana peserta didik diharapkan aktif berinteraktif dan memiliki pengalaman belajar; (2) carring community, pendidik sepenuhnya mencurahkan perhatian dan 
memandu kegiatan belajar, (3) jumping task, pemberian tugas belajar agar presetasi belajarnya lebih meningkat (Hobri et al., 2021).

Beberapa penelitian sebelumnya, seperti Maulana (2020); Sulistiawati (2021); Nurhikmayati (2019); Mawaddah \& Mahmudi (2021); Purwandi (2020) telah melakukan penelitian tentang pembelajaran matematika dengan pendekatan STEM dan kemampuan pemecahan masalah berbasis LSLC. Melainkan, beberapa penelitian di atas belum ada yang melakukan penelitian tentang kemampuan pemecahan masalah matematika dan kemandirian belajar dengan pendekatan STEM berbasis LSLC.

Kemampuan pemecahan masalah dan kemandirian belajar peserta didik di SMPN 1 Ngunut sebelum menerapkan pendekatan STEM berbasis LSLC dikategorikan rendah. Sebagaian besar peserta didik merasa kesulitan dalam mengungkapkan gagasan ketika diminta untuk menuliskan setiap informasi yang diberikan pada masalah tersebut. Selanjutnya, peserta didik juga tidak terbiasa menyusun dan melaksanakan rencana penyelesaian saat mencari solusi alternatif. Sama halnya dengan menarik kesimpulan. Peserta didik di SMPN 1 Ngunut cenderung tidak menuliskan kesimpulan walaupun sedang menyeleaikan soal esai. Dari segi aktifitas belajar baik peserta didik maupun pendidik di SMPN 1 Ngunut masih membutuhkan peningkatan. Hal itu dikarenakan selama pembelajaran berlangsung peserta didik masih banyak yang kurang aktif. Proses pembelajaran yang terpusat pada pendidik. Sebagaimana dengan pendidiknya, selagi kegiatan belajar mengajar juga tidak memberikan perhatian yang lebih pada setiap peserta didik. Oleh sebab itu, penelitian ini akan menggali tentang kemampuan pemecahan masalah dan tingkat kemandirian belajar dengan pendekatan STEM berbasis LSLC.

\section{METODE PENELITIAN}

Penelitian ini merupakan penelitian kualitatif. Data yang dideskripsikan adalah kemampuan pemecahan masalah dan kemandirian belajar dengan pendekatan STEM berbasis LSLC. Penelitian ini dilaksanakan di SMPN 1 Ngunut kelas VII saat semester genap tahun pelajaran 2020/2021. Pengumpulan data dalam penlitian ini melalui tes dan non tes.

Subjek penelitian dalam penelitian ini merupakan peserta didik kelas VII SMPN 1 Ngunut yaitu sebanyak 32 orang. Akan tetapi setelah diberikan angket kemandirian belajar, diambil tiga orang. Tiga peserta didik tersebut merupakan perwakilan yang memiliki kemandirian belajar tinggi, sedang, rendah. Tak hanya itu aja, penelitian ini juga mengikutsertakan pendidik dengan latar belakang pendidikan matematika. Hal itu dilakukan sebagai upaya untuk memantau proses pembelajaran bagaimana peserta didik mengikuti alur pembelajaran dengan pendekatan STEM berbasis LSLC.

Penelitian ini dilakukan melalui empat tahapan. Pertama, tahap persiapan. Di tahap ini melakukan survei terhadap sekolah yang telah dipilih sebagai tempat penelitian, peeliti mengadakan kesepakatan kepada guru matematika yang ada disekolah tersebut guna menetapkan materi yang akan dipakai dalam penelitian.

Kedua, tahap pelaksanaan. Pada tahap ini, peneliti mengamati aktivitas belajar peserta didik saat melaksanakan pembelajaran dengan pendekatan STEM berbasis LSLC. Di akhir proses pembelajaran peneliti memberikan angket kemandirian belajar pada peserta 
DOI: https://doi.org/10.24127/ajpm.v10i4.4416

didik. Kemudian, memberikan tes tertulis kepada peserta didik yang terpilih sebagai subjek penelitian.

Ketiga, deskripsi data. Tahap deskripsi data, dilaksanakan setelah memberikan angket kemandirian belajar dan soal pemecahan masalah matematika. Keempat, penarikan kesimpulan. Di tahap ini, peneliti menuliskan kesimpulan dari berbagai macam data yang telah diperoleh.

Instrumen pengumpulan data pada penelitian terdiri dari beberapa bentuk. Pertama, lembar observasi. Lembar obervasi ini berisikan delapan pernyataan yang menggambarkan kegiatan pendahuluan, isi dan penutup saat menerapkan pendekatan STEM berbasis LSLC. Kedua, tes. Tes yang diberikan kepada peserta didik guna untuk mengukur tingkat kemampuan pemecahan masalah matematika. setiap subjek penelitian diberikan 1 soal uraian. Ketiga, angket kemandirian belajar disusun dalam rangka untuk mengukur tingkat kemandirian belajar peserta didik. Ada empat pilihan jawaban yang digunakan pada angket kemandirian belajar. Pertanyaan yang diberikan adalah pertanyaan mengarah ke kegaiatan positif dan negatif. Pengelompokkan kemandirain belajar akan dilakukan dengan tiga tingkatan. Kualifikasi kemandirain belajar peserta didik didasarkan pada kriteria seperti yang akan disajikan pada Tabel 1 .

Tabel 1. Kualifikasi kemandirian belajar matematika peserta didik

\begin{tabular}{ccc}
\hline No & $\begin{array}{c}\text { Kemandirian } \\
\text { Belajar }\end{array}$ & \multicolumn{1}{c}{ Kriteria } \\
\hline 1. & Tinggi (T) & $s \geq \bar{x}+S D$ \\
2. & Sedang (S) & $\bar{x}-S D<s<\bar{x}+S D$ \\
3. & Rendah (R) & $s \leq \bar{x}+S D$ \\
\hline $\bar{x}:$ rata - rata skor kemandirian belajar; & \\
$S D$ & $:$ standar deviasi; \\
$S$ & $:$ skor kemandirian belajar
\end{tabular}

Pengumpalan data yang diigunakan dalam penelitian ini dengan beberapa tahapan. Tahap pengumpulan data dilakukan dengan beberapa langkah. Langkah pertama, mengoreksi lembar observasi, angket kemandirian belajar dan tes kemampuan pemecahan masalah matematika. Lembar observasi disusun oleh peneliti agar mengetahui perkembangan aktivitas peserta didik saat menggunakan pendekatan STEM berbasis LSLC. Angket kemandirian belajar yang diberikan nantinya membantu peneliti dalam melakukan pengkatagorian kemandirain belajar matematika mulai dari kemandirian belajar tinggi, sedang hingga rendah. Pemilihan subjek penelitian sesuai apa yang dikerjakan saat tes kemampuan pemecahan masalah dengan tingkat kemandirian belajar yang berbeda. Tahap penyajian data yaitu menampilkan kumpulan data yang sudah terorganisir. Data yang disajikan oleh peneliti adalah lembar observasi, angket kemandirian belajar, tes kemampuan pemecahan masalah. Tahap verifikasi data, dilakukan dengan menarik kesimpulan sesuai dengan data yang telah disajikan pada penelitian ini.

Pada penelitian ini uji keabsahan data yang digunakan adalah triangulasi subjek. Triangulasi subjek dilakukan dengan meninjau kembali kepastian data dari pihak peserta didik dan maupun pendidik.

\section{HASIL DAN PEMBAHASAN}

Penelitian ini dilakukan dengan beberapa tahapan. Pertama, pendahuluan. Pada tahap ini, mendekskripsikan kegiatan belajar mengajar dengan pendekatan STEM berbasis LSLC. Tahap kedua, pelaksanaan kegiatan belajar mengajar dilakukan sebanyak empat kali di sekolah secara tatap muka dan dua kali 
DOI: https://doi.org/10.24127/ajpm.v10i4.4416

dilaksanakan di rumah. Proses pembelajaran yang dilaksanakan di rumah dilakukan secara daring. Pendidik tetap menyampaikan konsep aritmatika sosial dengan pembuatan tape secara daring. Tahap ketiga, melakukan tes kemandirian belajar untuk memilih subjek penelitian. Kemudian, dilakukan tes kemampuan pemecahan masalah. Tes kemampuan masalah dilaksanakan setelah kegiatan belajar mengajar dengan pendekatan STEM berbasis LSLC.

Pendidik melakukan pembelajaran dengan membagi peserta didik menjadi empat orang dalam satu kelompok. Peserta didik nantinya diminta untuk menyelesaikan solusi alternatif dengan teman sekelompoknya. Masalah yang diberikan setiap kelompok merupakan masalah yang disajikan pada Lembar Kerja Siswa (LKS).

LKS yang diberikan ke pada peserta didik disusun dengan beberapa tahapan. Pembelajaran dengan pendekatan STEM melalui tahapan pembuatan tape yang terdiri atas science, langkah - langkah pembuatan dan fermentasi tape; technology, menggunakan software powerpoint ketika mempresentasikan hasil diskusi; engineering, alat - alat yang digunakan dalam membuat tape; mathematics yang digunakan dalam menyusun LKS juga terdiri atas beberapa tahapan yang menyesuaikan degan indikator kemampuan pemecahan masalah.

Pertama, tahap memahami masalah. Pada tahap ini peserta didik diberikan masalah tentang harga bahan pokok pembuatan tape. Kedua, tahap menyusun rencana. Peserta didik diminta untuk menulis kembali pengeluaran saat memproduksi tape. Ketiga, melaksanakan rencana. Dimana, peserta didik diminta untuk menentukan penyelesaian dari masalah yang diberikan. Keempat, memerika kembali. Di tahap akhir ini peserta didik akan diberi arahan agar melihat kembali hasil penyelesaian masalah.

Dengan kata lain, pembelajaran pendekatan STEM berbasis LSLC akan merekomendasikan pengetahuan tentang artimatika sosial. Penyampaian materi tersebut dilakukan dengan mengusulkan apersepsi kedalam keidupan sehari - hari. Selain itu, pendekatan STEM berbasis LSLC dapat menumbuhkembangkan aktifitas peserta didik ketika kegiatan belajar mengajar berlangsung. Pernyataan tersebut dapat didukung dengan adanya pengamatan aktivitas peserta didik yang dilakukan peneliti saat pembelajaran menggunakan pendekatan STEM berbasis LSLC. Aktivitas peserta didik saat pembelajaran dengan pendekatan STEM Berbasis LSLC dapat digambarkan melalui Grafik 1.

\section{Aktivitas Peserta Didik}

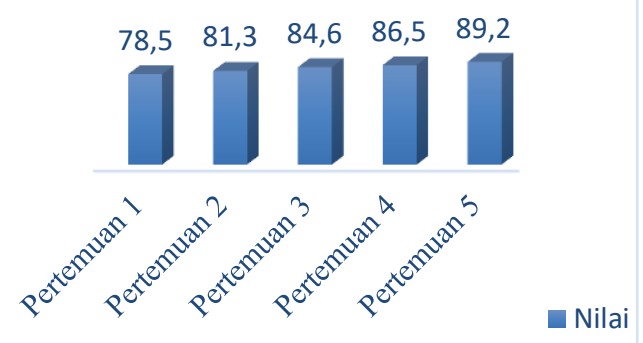

Grafik 1. Aktivitas peserta didik saat pembelajaran dengan pendekatan STEM berbasis LSLC

Aktivitas peserta didik aktif dikatakan aktif saat mencapai interval $70 \% \leq P_{5}<90 \%$ dan dikatakan sangat aktif berada pada interval $90 \% \leq P_{5}<$ $100 \%$ pada setiap pertemuan. Berdasarkan grafik 1 diketahui bahwa rata - rata aktivitas peserta didik selalu terjadi peningkatan setiap pertemuan. Selain itu, dari grafik di atas dapat 
DOI: https://doi.org/10.24127/ajpm.v10i4.4416

dinyatakan bahwa aktivitas peserta didik termasuk dalam kategori aktif. Data hasil kemandirain belajar peserta didik pada penelitian ini akan disajikan pada Tabel 2.

Tabel 2. Hasil angket kemandirian belajar peserta didik

\begin{tabular}{ccc}
\hline No & Kemandirian Belajar & Hasil \\
\hline 1. & Tinggi $(\mathrm{T})$ & 7 orang \\
2. & Sedang $(\mathrm{S})$ & 19 orang \\
3. & Rendah $(\mathrm{R})$ & 6 orang \\
\hline
\end{tabular}

Berlandaskan Tabel 2, bahwa ada 7 peserta didik dengan kemandirian belajar tinggi, 19 peserta didik memiliki kemandirian sedang, dan 6 peserta didik dengan kemandirian belajar rendah. Dari hasil angket kemandirian belajar tersebut, peneliti memilih subjek penelitian dengan setiap kategori kemandirian belajar akan diambil satu peserta didik.

Hasil kerja pada tes kemampuan peserta didik digunakan sebagai acuan dalam memilih subjek penelitian. Subjek penelitian yang telah dipilih akan diberi inisial KBT (kemandirian belajar tinggi), KBS (kemandirian belajar sedang), KBR (kemandirian belajar rendah). Hasil tes kemampuan pemecahan masalah subjek KBT akan disajikan pada Gambar 1.

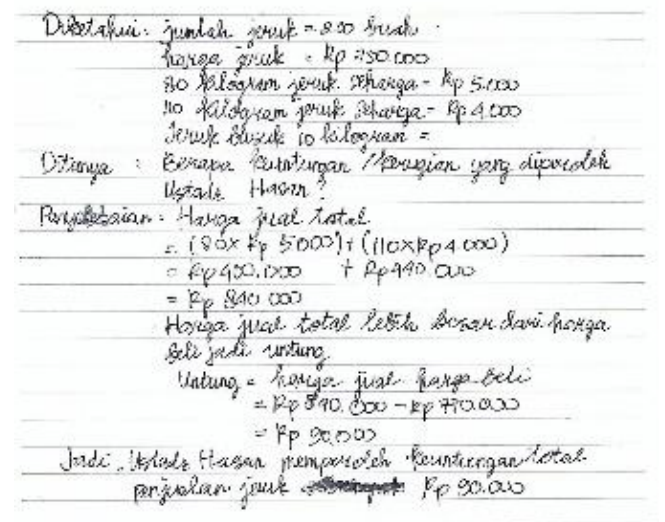

Gambar 1. Hasil tes kemampuan pemecahan masalah matematis subjek KBT
Berdasarkan Gambar 1, saat memecahkan masalah di tahap memahami masalah, subjek KBT mampu mencantumkan semua informasi baik komponen - komponen apa yang diketahui seperti jumlah jeruk 200 buah, harga jeruk Rp 750.000, 80 $\mathrm{kg}$ jeruk dijual seharga Rp 5.000/kg, $110 \mathrm{~kg}$ dijual seharga $\mathrm{Rp} 4.000 / \mathrm{kg}$ dan apa yang ditanya yaitu menentukan berapa keuntungan dari jeruk yang dijual oleh Ust. Hasan. Pada indikator rencana penyelesaian, subjek KBT mampu menyusun rencana dengan menuliskan langkah-langkah penyelesaian. Subjek KBT mampu menentukan harga jual total dengan benar. Selanjutnya, KBT mampu menentukan keuntungan penjualan jeruk dengan sesuai dengan rumus yang telah ditentukan, sehingga diperoleh keuntungan penjualan jeruk sebesar Rp 90.000. Indikator terakhir yaitu, memeriksa kembali, KBT mampu menarik kesimpulan. Kesimpulan yang dikemukakan oleh KBT yaitu keuntungan yang diperoleh ustadz Hasan setelah menjual jeruk sebesar Rp 90.000. Hal tersebut menunjukkan bahwa kesimpulan yang dikemukakan subjek KBT sesuai dengan apa yang diketahui dan ditanyakan. KBT juga memiliki kepercayaan yang cukup dalam menyelesaikan masalah yang diberikan. Hasil tes kemampuan pemecahan masalah subjek KBS ada pada Gambar 2.

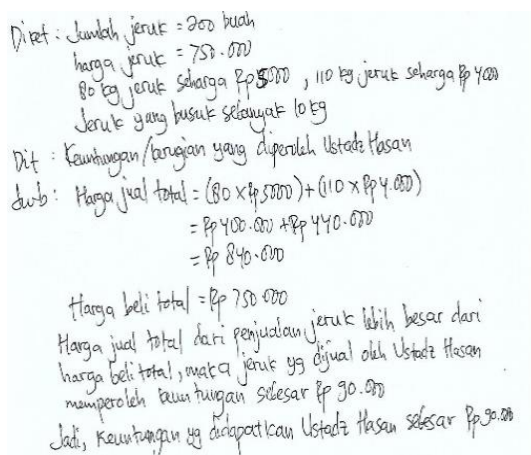

Gambar 2. Hasil tes kemampuan pemecahan masalah matematis subjek KBS 
DOI: https://doi.org/10.24127/ajpm.v10i4.4416

Hal serupa juga terjadi pada subjek KBS sesuai dengan gambar Hasil Tes Kemampuan Pemecahan Masalah Matematis Subjek KBS bahwa pada indikator memahami masalah, mampu mengkomunikasikan semua informasi yang ada soal tak terkecuali komponen - komponen yang apa yang diketahui dan ditanya. Beberapa komponen yang termasuk dalam apa yang diketahui adalah jumlah jeruk 200 buah, harga jeruk Rp 750.000, $80 \mathrm{~kg}$ jeruk dijual seharga Rp 5.000/kg, 110 $\mathrm{kg}$ dijual seharga $\mathrm{Rp} 4.000 / \mathrm{kg}$ dan komponen yang ditermasuk dalam kategori apa yang ditanya adalah keuntungan yang diperoleh Ustadz Hasan. Subjek KBS juga dapat menentukan rencana penyelesaian dengan menemukan harga jual total dengan benar. Meskipun terdapat ketidaksempurnaan pada jawaban yang diberikan. Karena subjek KBS tidak menuliskan rumus keuntungan dan langsung menuliskan harga jual total dari penjualan jeruk oleh Ustadz Hasan lebih besar dari harga beli, maka Ustadz Hasan memperoleh keuntungan sebesar Rp 90.000. Sehingga subjek KBS mampu menghitung keuntungan yang diperoleh Ustadz Hasan. Setiap perhitungan yang dilakukan oleh subjek KBS dilakukan dengan benar. Di tahap memeriksa kembali subjek KBS mampu menarik kesimpulan dengan benar dan sesuai dengan apa yang diketahui dan ditanya. Kesimpulan yang dikemukakan oleh subjek KBS yaitu keuntungan yang diperoleh Ustadz Hasan sebesar Rp 90.000 .

Hasil tes kemampuan pemecahan masalah subjek KBR akan disajikan pada Gambar 3.

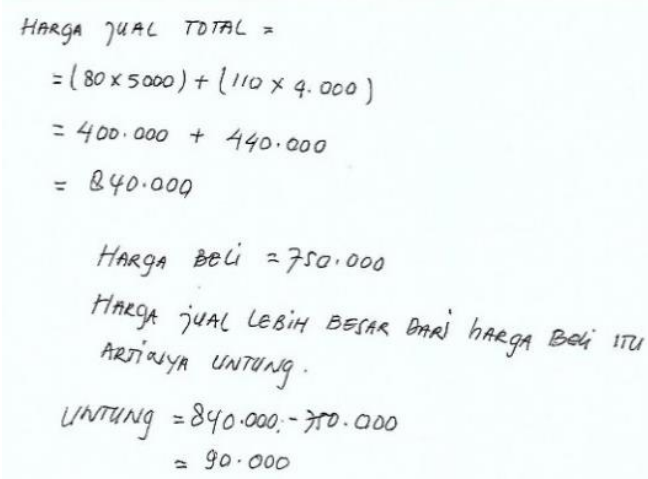

Gambar 3. Hasil tes kemampuan pemecahan masalah matematis subjek KBR

Berdasarkan gambar Hasil Tes Kemampuan Pemecahan Masalah Matematis Subjek KBR, subjek KBR ketika indikator memahami masalah, tidak mampu menyampaikan semua informasi pada soal. Subjek KBR mengalami kesulitan mengungkapkan ide - ide ke dalam kalimat matematika. Kesulitan lainnya yang dialami oleh subjek KBR adalah tidak menentukan rencana secara rinci walaupun langkah - langkah penyelesaian yang disampaikan benar. Akan tetapi, subjek KBR mampu menuliskan pernyataan harga jual lebih besar dari pada harga beli, itu artinya untung. Dari pernyataan tersebut dapat terlihat bahwa subjek KBR memahami konsep untung / rugi dalam materi aritmetika. Subjek KBR mampu menentukan keuntungan yang diperoleh Ustadz Hasan. Ditunjukkan dengan perhitungan yang benar dan tepat yaitu sebesar Rp 90.00. Disisi lain, pada indikator memeriksa kembali, subkek KBR tidak dapat menuliskan kesimpulan. Dengan kata lain subjek KRS tidak dapat mencapai indikator memeriksa kembali dengan baik. Karena subjek KBR, memiliki kepercayaan diri yang kurang, sehingga kesulitan dalam mengungkapkan gagasan. 
DOI: https://doi.org/10.24127/ajpm.v10i4.4416

Proses pembelajaran dengan pembelajaran STEM berbasis LSLC membuahkan hasil yang baik. Karena, dengan pendekatan tersebut aktivitas belajar, kemampuan pemecahan masalah, dan kemandirian peserta didik menjadi meningkat. Meskipun perancangan pendukung pembelajaran membutuhkan waktu cukup lama. Hal tersebut juga sejalan dengan Maulana (2020) bahwa untuk menyiapkan pembelajaran dengan pendekatan STEM memang membutuhkan waktu yang cukup lama. Akan tetapi, dengan pendekatan STEM pada pembelajaran matematika, peserta didik akan lebih mandiri dalam menyelesaikan permasalahan. Ketika mencari solusi alternatif peserta didik tidak bergantung pada orang lain dan memiliki kepercayaan diri yang cukup tinggi dalam mengemukakan pendapat. Lebih dari kemampuan pemecahan masalah dan kemandirian dapat berkembang dengan baik dengan menerapkan pembelajaran dengan pendekatan STEM berbasiss. Seperti yang dikemukakan oleh Purwandi et al., (2020) bahwa LSLC dapat meningkatkan kemampuan pemecahan masalah peserta didik dan melatih komunikasi saat kegiatan berdikusi.

Kemandirian belajar peserta didik juga dapat meningkat dengan bantuan pendekatan STEM berbasis LSLC. Senada dengan yang diungkapkan Edy (2017) bahwa saat fase perencanaan dalam kemandirian belajar peserta didik memiliki kesiapan yang lebih baik dalam mempersiapkan materi yang akan disampaikan. Terlebih, saat berdiskusi dengan kelompoknya lebih aktif saat pembelajaran.

\section{KESIMPULAN DAN SARAN}

Berdasarkan hasil analisis di atas bahwa pembelajaran dengan pendekatan
STEM berbasis LSLC mampu menumbuhkembangkan kemandirian belajar dan kemampuan pemecahan masalah matematika. Kemampuan pemecahan masalah dengan kemandirian belajar tinggi, mampu menyelesaikan masalah menggunakan empat tahap. Hanya tiga indikator yang dapat dicapai oleh peserta didik yang memiliki kemapuan pemecahan masalah matematika dengan kemandirian belajar sedang Sedangkan peserta didik dengan kemampuan pemecahan masalah matematika dengan kemandirian belajar rendah hanya memenuhi satu indikator saja.

Peneliti menyarankan agar penelitian lebih lanjut dapat dilakukan pada berbagai topik penelitian yang lebih luas di tingkat lain. Ada banyak bidang dalam matematika, seperti aljabar dan statistik, yang dapat digunakan sebagai pilihan untuk studi lebih beragam yang memiliki keterkaitan dengan pendekatan STEM Berbasis LSLC.

\section{DAFTAR PUSTAKA}

Abdullah, N., Halim, L., \& Zakaria, E. (2014). VStops: A Thinking Strategy and Visual Representation Approach in Mathematical Word Problem Solving toward Enhancing STEM Literacy. Eurasia Journal of Mathematics Science and Technology Education, 10(3), 165-174.

https://doi.org/10.12973/eurasia.2 014.1073a

Bjuland, R., \& Mosvold, R. (2015). Lesson study in teacher education: Learning from a challenging case. Teaching and Teacher Education, 52, 83-90.

Darling-Hammond, L., Flook, L., CookHarvey, C., Barron, B., \& Osher, 
DOI: https://doi.org/10.24127/ajpm.v10i4.4416

D. (2019). Implications for educational practice of the science of learning and development. Applied Developmental Science, $0(0), 1-44$.

Edy, S. (2017). Penerapan Lesson Study dalam Peningkatan FKIP UM Gresik. Didaktika: Jurnal Pemikiran Pendidikan, 21(2), 110-123.

Ekananda, A., Pujiastuti, H., \& S, C. A. H. F. (2020). Analisis Kemampuan Pemecahan Masalah Matematis Ditinjau dari Kemandirian Belajar Siswa. WILANGAN: Jurnal Inovasi Dan Riset Pendidikan Matematika, 1(4), 367-382. http://www.jurnal.untirta.ac.id/ind ex.php/wilangan

Ekawati, N. W., Iswari, R. S., \& Lisdiana. (2018). The influence of scientific independence towards students' content analysis and science process skills on cell metabolism topic. Jurnal Pendidikan IPA Indonesia, 7(4), 420-427.

Frey, B. B. (2018). STEM Education. In The SAGE Encyclopedia of Educational Research, Measurement, and Evaluation. Departement Education and Skills.

Hobri, Murtikusuma, R. P., Oktavianingtyas, E., Susanto, \& Putri, I. W. S. (2021). The students' interaction in mathematics collaborative learning, caring community, and jumping task. Journal of Physics: Conference Series, 1832(1), 0-12.

Hurst, B., Wallace, R., \& Nixon, S. B. (2013). The impact of social interaction on student learning. Reading Horizons, 52(4), 375398.
Maulana, M. (2020). Penerapan Model Project Based Learning Berbasis Stem Pada Pembelajaran Fisika Siapkan Kemandirian Belajar Peserta Didik. Jurnal Teknodik, 2, 39.

Mawaddah, S., \& Mahmudi, A. (2021). Analisis Kemampuan Komunikasi Matematika Siswa Melalui Penggunaan Project-Based Learning Terintegrasi STEM. AKSIOMA: Jurnal Program Studi Pendidikan Matematika, 10(1), 167-182.

Murdiyani, N. M., Zulkardi, Putri, R. I. I., Van Eerde, D., \& Van Galen, F. (2013). Developing a model to support students in solving subtraction. Journal on Mathematics Education, 4(1), 95112.

NCTM. (2000). Principles and Standards for School Mathematic. Copyright (C) 2000 by The National Council of Teachers of Mathematics.

Nurhikmayati, I. (2019). Implementasi STEAM Dalam Pembelajaran Matematika. Didactical Mathematics, 1(2), 41-50. https://doi.org/10.31949/dmj.v1i2. 1508

Purwandi, D., Susanto, \& Hobri. (2020). Development of remedial mathematics learning based on lesson study for learning community against students' problem solving analysis capabilities. Journal of Physics: Conference Series, 1563(1).

Razak, F., Sutrisno, A. B., \& Kamaruddin, R. (2018). Deskripsi Pemecahan Masalah Matematika berdasarkan Langkah Polya ditinjau dari Kepribadian Siswa Tipe Melankolis. Prisma Sains: Jurnal Pengkajian Ilmu Dan 
DOI: https://doi.org/10.24127/ajpm.v10i4.4416

Pembelajaran Matematika Dan IPA IKIP Mataram, 6(2), 86.

Sam, H. N., \& Qohar, A. (2016). Pembelajaran Berbasis Masalah Berdasarkan Langkah - Langkah Polya untuk Meningkatkan Kemampuan Menyelesaikan Soal Cerita Matematika. Kreano, Jurnal Matematika KreatifInovatif, 6(2), 156.

Simamora, R. E., Saragih, S., \& Hasratuddin, H. (2018). Improving Students' Mathematical Problem Solving Ability and Self-Efficacy through Guided Discovery Learning in Local Culture Context. International Electronic Journal of Mathematics Education, 14(1), 61-72.

Siregar, N. C., Rosli, R., Maat, S. M., \& Capraro, M. M. (2019). The Effect of Science, Technology, Engineering and Mathematics (STEM) Program on Students' Achievement in Mathematics: A Meta-Analysis. International Electronic Journal of Mathematics Education, 1(1), 112.

https://doi.org/10.29333/iejme/58 85

Sulistiawati, S., Juandi, D., \& Yuliardi, R. (2021). Pembelajaran Terintegrasi Stem Untuk Meningkatkan Literasi Matematis Mahasiswa Calon Guru Matematika Pada Perkuliahan Pra-Kalkulus 1. Teorema: Teori Dan Riset Matematika, 6(1), 82. https://doi.org/10.25157/teorema. v6i1.4727

Widoretno, S., \& Dwiastuti, S. (2019). Improving students' thinking skill based on class interaction in discovery instructional: A case of lesson study. Jurnal Pendidikan
IPA Indonesia, 8(3), 347-353.

Wulandari, A. Y. R., Agustina, N., Hidayati, Y., \& Tsulutsya, F. B. (2019). Increasing students' problem-solving ability on the pressure concept through modeleliciting activities (MEAs). AIP Conference Proceedings, 2202(December). 